\title{
Benchmark: Biomass Production in Eucalyptus Plantations as a Consequence of Fertilization
}

\author{
Paulo Henrique Rodrigues dos $\operatorname{Santos}^{1}$ (D), Reynaldo Campos Santana ${ }^{1}$ (D), \\ Marcio Leles Romarco de Oliveira ${ }^{1}$ (D), Francisco Sérgio Gomes ${ }^{2}$ (iD \\ ${ }^{1}$ Universidade Federal dos Vales do Jequitinhonha e Mucuri - UFVJM, Diamantina/MG, Brasil \\ ${ }^{2}$ Gerdau Florestal SA, Três Marias/MG, Brasil
}

\begin{abstract}
The objective of this work was to evaluate the effects of fertilization, spatial arrangement and age on the biomass production in eucalyptus. The experiment was set up in a randomized block design with four replicates. Overall, 15 fertilizations adopted by forest companies in plots were evaluated, and two arrangements, $3.0 \times 3.0 \mathrm{~m}$ and $6.0 \times 1.5 \mathrm{~m}$, were tested in subplots. Diameter at $1.30 \mathrm{~m}$ and total height were measured at 12, 24,36, 48 and 60 months after planting to estimate trunk biomass. Dependence between commercial fertilization and arrangement were observed for trunk biomass. The biomass production rate in treatments where higher amounts of nutrients were applied decreased from the second year. The $3.0 \times 3.0 \mathrm{~m}$ arrangement proved to be the most attractive option at 60 months using treatment with $2000 \mathrm{~kg}$ of agrosilicon, $400 \mathrm{~kg}$ of reactive phosphate, $130 \mathrm{~kg}$ of $04: 26: 16+0.5 \% \mathrm{Cu}+0.5 \% \mathrm{Zn}$ and $150 \mathrm{~kg}$ of $\mathrm{KCl}+1 \% \mathrm{~B}$.
\end{abstract}

Keywords: space arrangement, forest fertilization, forestry. 


\section{INTRODUCTION}

Rapid technological development and increasing changes in market profiles compel organizations to constantly seek out and develop new solutions in order to know their position and to not stop pursuing excellence (Macedo-Soares \& Ratton, 1999). In the context in which forestry companies are inserted, the concern with maintaining or increasing the quality of silvicultural processes is fundamental. Thus, well-structured information base is required to assist decision-making. For this, it is important to develop processes for performance measurement that, according to Macedo-Soares \& Ratton (1999), should be aligned with the organization's strategic objectives. The benchmark process, as a tool for performance measurement, is an instrument that can contribute to improve the performance of the productive chain.

The main eucalyptus producing companies for bioenergy and pulp in the state of Minas Gerais adopt similar silvicultural technologies from planting to harvesting, such as integrated pest management, soil tillage, competing vegetation control and harvesting. Fertilization of stands is the main silvicultural practice that differs among companies. Companies generally have an experimental network that is evaluated over several years and used to calibrate fertilization recommendations specific to the edaphoclimatic conditions of stands. The nutritional management of eucalyptus stands in Brazil has provided significant gains and has ensured the sustainability of forest sites (Gonçalves et al., 2008; Stape et al., 2010).

Different fertilization recommendations under similar soil and climatic conditions are not uncommon, although productivity gains are not always obtained where higher amounts of nutrients are applied (Stape et al., $2008,2010)$. The response magnitude when applying fertilizers varies according to the type and time of soil preparation, competition with undesirable plants, history of area use, fertilizer and corrective doses, spatial arrangement, water availability and soil and climatic conditions (Smethurst et al., 2003; Whitehead \& Beadle, 2004; Santana et al., 2008; Tarouco et al., 2009; Stape et al., 2010; Silva et al., 2013; Pulito et al., 2015).

In terms of forestry, one of the main decision making elements is the analysis of the optimal spatial arrangement through growth studies of individuals under different space conditions. This will not only influence the individual growth of plants, but also the final production by area (Magalhães et al., 2006). The choice of spacing arrangement gives each tree enough space to achieve maximum growth with better quality and lower cost (Magalhães et al., 2006; Martins et al., 2009). The production of wood, cellulosic pulp or raw material for bioenergy production can be maximized with different planting arrangements, since final products have different specificities that can be influenced by the type of forest management adopted.

This work is aligned with recent efforts and initiatives of forestry companies to develop more effective systems. In the specific case of this study, it is based on evaluating the effect of commercial fertilizations used by companies operating in the state of Minas Gerais on eucalyptus production in order to not only provide support, but also decisively contribute to the effective implementation and consolidation of organizational improvement strategies.

Given the importance of nutrition in the wood production process, the aim of this work was to use the benchmark to evaluate the effects of fertilization, spacing arrangement and age on the production of eucalyptus trunk biomass.

\section{MATERIAL AND METHODS}

This study was developed in an area belonging to the Gerdau group, in the municipality of Três Marias - MG (latitude $18^{\circ} 15^{\prime} 37^{\prime \prime}$ south and longitude $45^{\circ} 04^{\prime} 57^{\prime \prime}$ west). The predominant climate in the region is Aw according to the Köppen classification (hot and rainy summers and mild and dry winters), with average annual temperature of $23^{\circ} \mathrm{C}$, mean annual rainfall of $1,242 \mathrm{~mm}$ (Meneses et al., 2015) and in a homogeneous area characterized by alic and dystrophic Red-Yellow Latosol (Table 1).

In order to carry out the benchmark, commercial fertilization was operationally adopted by 15 large forest companies located in the state of Minas Gerais, which use wood for the production of charcoal or cellulose. A randomized block design implementing a strip scheme was adopted, with dimensions of $36 \times 84 \mathrm{~m}$. Four blocks were installed using plot treatments of the 15 operational fertilizations (Table 2), and two spacing arrangements $(3.0 \times 3.0 \mathrm{~m}$ and $6.0 \times 1.5 \mathrm{~m})$ were tested in subplots ( $36 \times 42)$ using GG100 clone (E. urophylla $\times$ E. grandis). Ant control was carried out 
Table 1. Chemical and physical characterization of the soil of the study area.

\begin{tabular}{|c|c|c|c|c|c|c|c|c|c|c|c|}
\hline \multirow{2}{*}{$\begin{array}{c}\text { depth } \\
(\mathrm{cm})\end{array}$} & \multirow{2}{*}{ pH } & $\mathbf{P}$ & $\mathbf{K}$ & $\mathrm{Ca}$ & Mg & Al & $\mathrm{H}+\mathrm{Al}$ & O.M. & Sa & $\mathbf{S}$ & $\mathrm{C}$ \\
\hline & & \multicolumn{2}{|c|}{$\mathrm{mg} \mathrm{dm}^{-3}$} & \multicolumn{4}{|c|}{ cmolc. $\mathrm{dm}^{-3}$} & \multicolumn{4}{|c|}{ dag.kg-1 } \\
\hline $0-20$ & 4.7 & 0.87 & 16.2 & 0.18 & 0.09 & 0.50 & 3.30 & 1.5 & 78 & 10 & 12 \\
\hline $20-40$ & 4.6 & 0.53 & 11.2 & 0.09 & 0.05 & 0.47 & 3.14 & 1.2 & 80 & 4 & 16 \\
\hline
\end{tabular}

O.M.: Organic Matter; Sa: Sand; S: Silt; C: Clay. Extractors: M.O.: Oxi-Red.; pH in water - Relationship 1:2.5; P, K: Mehlich I; Al, Ca, $\mathrm{Mg}: \mathrm{KCl} ; \mathrm{H}+\mathrm{Al}$ : Buffered SMP

Table 2. Commercial fertilization by treatment, application time (TA) and amount of products used.

\begin{tabular}{|c|c|}
\hline Treatment & Product (TA - kg.ha-1) \\
\hline 1 & $\begin{array}{l}\text { Agrosilicon (TA1 - 2000); Reative Phosphate (TA2 - 400); 04:26:16+0.5\%Cu+0.5\%Zn (TA3 - 130); } \\
\text { KCl+1\%B (TA4 - 150) }\end{array}$ \\
\hline 2 & $\begin{array}{l}\text { Limestone Agrimag (TA1 - 1500); Plaster (TA1 - 1500); Simple Superphosphate }+0.5 \% \text { B }+0.5 \% \text { Cu+0.5\%Zn } \\
\text { (TA2 - 300); 06:30:06+0.5\%B+0.5\%Zn (TA3 - 150); 20:05:20 (TA4 - 150); 20:05:20 (TA5 - 150); Boron } \\
\text { (liquid form) (TA6 - 2) }\end{array}$ \\
\hline 3 & $\begin{array}{l}\text { Limestone Agrimag (TA1 - 1500); Reative Phosphate (TA2 - 300); 06:30:12 (TA3 - 175); 08:00:32+0.7\%B } \\
\text { (TA4 - 130); KCl (TA5 - 150) }\end{array}$ \\
\hline 4 & $\begin{array}{l}\text { Agrosilicon (TA1 - 1500); Reative Phosphate (TA2 - 400); 06:30:06+0.5\%B+0.5\%Zn+0.5\%Cu (TA3 - 110); } \\
\mathrm{KCl}+1.2 \% \mathrm{~B}+1 \% \mathrm{Zn}+0.5 \% \mathrm{Cu}(\mathrm{TA} 4-150) ; \mathrm{KCl}+1.2 \% \mathrm{~B}+1 \% \mathrm{Zn}+0.5 \% \mathrm{Cu}(\mathrm{TA} 5-150) ; \text { Borax (TA6 - 25) }\end{array}$ \\
\hline 5 & $\begin{array}{l}\text { Limestone Rima (TA1 - 1000); Reative Phosphate (TA2 - 450); 06:30:06+0.5\%B+0.5\%Zn (TA3 - 100); } \\
\mathrm{KCl}+1 \% \mathrm{~B}(\mathrm{TA} 4-150) ; \mathrm{KCl}+1 \% \mathrm{~B}(\mathrm{TA} 5-150)\end{array}$ \\
\hline 6 & Limestone Rima (TA1 - 1000); Basifós (TA2 - 300); KCl+1\%B (TA4 - 150); KCl+1\%B (TA5 - 150) \\
\hline 7 & $\begin{array}{l}\text { Limestone Rima (TA1 - 1000); Phosphate of the Araxá (TA2 - 650); 06:30:06+0.5\%B+0.5\%Zn (TA3 - 100); } \\
\mathrm{KCl}+1 \% \mathrm{~B}(\mathrm{TA} 4-150) ; \mathrm{KCl}+1 \% \mathrm{~B}(\mathrm{TA} 5-150)\end{array}$ \\
\hline 8 & $\begin{array}{l}\text { Limestone Rima (TA1 - 1000); 03:19/30:01+0.3\%B+0.25\%Zn+0.25\%Cu+6.6\%S (TA2 - 300); KCl+1\%B } \\
\text { (TA4 - 150); KCl+1\%B (TA5 - 150) }\end{array}$ \\
\hline 9 & $\begin{array}{l}\text { Pre-lime (TA1 - 1000); 03:19/30:00+0.3\%B+0.25\%Zn+0.25\%Cu+6.6\%S+1\%Mg (TA2 - 300); } \\
\text { 00:00:38+16\%Mg+0.7\%B (TA4 - 230); 00:00:38+16\%Mg+0.7\%B (TA5 - 230) }\end{array}$ \\
\hline 10 & $\begin{array}{l}\text { Pre-lime (TA1 - 420); Balloon powder (TA1 - 20000); 06:30:06+0.5\%B+0.5\% Zn (TA3 - 100); KCl+1\%B } \\
\text { (TA4 - 175); Copper and Borogran (TA6 - } 8 \text { e } 24)\end{array}$ \\
\hline 11 & $\begin{array}{l}\text { Limestone Agrimag (TA1 - 2000); 04:18/30:04+0.2\%Zn+0.25\%B+0.2\%Cu (TA2 - 390); 15:00:30 } \\
\text { (TA4 - 170); KCl+1\%B (TA5 - 220) }\end{array}$ \\
\hline 12 & $\begin{array}{l}\text { Limestone Agrimag (TA1 - 500); Reative Phosphate (TA2 - 400); 06:30:06+1\%B+1\%Zn+1\%Cu } \\
\text { (TA3 - 140); KCl (TA4 - 150); KCl (TA5 - 150); Borogran (TA6 - 20) }\end{array}$ \\
\hline 13 & $\begin{array}{l}\text { Limestone Rima (TA1 - 1500); Triple Superphosphate (TA2 - 170); 04:28:10 (TA3 - 100); 15:00:15+0.5\%B } \\
\text { (TA4 - 120); Borogran (TA6 - 25) }\end{array}$ \\
\hline 14 & $\begin{array}{l}\text { Limestone Agrimag (TA1 - 2000); Plaster (TA1 - 500); Simple Superphosphate (TA2 - 300); } \\
\text { 6:30:06+0.2\%B+1\%Zn+1\%Cu (TA3 - 150); 20:05:20 (TA4 - 120); 18:00:18 (TA5 - 350); 15:00:30 } \\
\text { (TA6 - 400) }\end{array}$ \\
\hline 15 & $\begin{array}{l}\text { Limestone Agrimag (TA1 - 1500); Reative Phosphate (TA2 - 610); 10:28:06+1\%B (TA3 - 150); } \\
\text { 20:00:20+2\%B (TA4 - 150); Borogran (TA6 - 30) }\end{array}$ \\
\hline
\end{tabular}

Application times (TA) were the following: TA1: 15 days before planting, in a $1 \mathrm{~m}$ strip on the planting line, without incorporation; TA2: 7 days before planting applied with subsoiler $40 \mathrm{~cm}$ deep; TA3: planting, side furrows $20 \mathrm{~cm}$ from the plant and $10 \mathrm{~cm}$ deep; TA4: 120 days after planting in cup projection, without incorporation; TA5: 480 days after planting in cup projection, without incorporation; and TA6: 840 days after planting in cup projection, without incorporation.

using granulated formicide bait following a systematic method throughout the area and specifically located whenever necessary. Control of competing vegetation was carried out with herbicide before installing the experiment and whenever necessary after planting.

In each experimental unit, diameter was measured at $1.30 \mathrm{~m}$ of soil height (Dap, $\mathrm{cm})$, the total height $(\mathrm{Ht}, \mathrm{m})$ and trunk biomass was estimated $\left(B_{\text {trunk }}, \mathrm{Mg}\right.$ tree $\left.{ }^{-1}\right)$ for
80 central plants at 12, 24, 36, 48 and 60 months, using the clone-specific Equation 1.

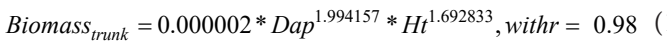

Data were submitted to analysis of variance by the F test, and means were compared by the Scott-Knott's test at 5\% using the Sisvar statistical software (Ferreira, 2011). 
In order to evaluate the relative performance of treatments, operational fertilizations of all treatments were converted into amounts of nutrients applied per treatment, regardless of time of application. The amounts applied per nutrient were subsequently and empirically grouped into five categories: very high, high, intermediate, low and not applied. Each category was characterized by a distinct symbol. Fertilizations of each treatment have been operationally used by large companies and were calibrated by field experiments over the years. Therefore, the denomination of adopted categories does not mean that there was a nutrient limitation or excess for biomass production. Ranks were created to allow a comparison of the performance in relation to the fertilization used.

\section{RESULTS}

The growth in trunk biomass varied according the commercial fertilizations adopted in all evaluated months, and only at 48 months among arrangements $(\mathrm{P} \leq 0.05)$ (Table 3$)$. A significant effect for the interaction of commercial fertilization $\mathrm{x}$ arrangement $(\mathrm{P} \leq 0.05)$ was verified at 12, 24, 36, 48 and 60 months (Table 3), evidencing that fertilization and arrangement factors are dependent on trunk biomass production, which means that the behavior of the fertilization adopted depends on the arrangement variation. At 60 months in arrangements of $3.0 \times 3.0 \mathrm{~m}$ and $6.0 \times 1.5 \mathrm{~m}$, trunk biomass production presented average values of

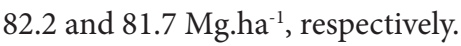

Arrangements $3.0 \times 3.0 \mathrm{~m}$ and $6.0 \times 1.5 \mathrm{~m}$ provided different biomass values among treatments at all ages measured; thus, trunk biomass changed as a function of treatment. Experiments of commercial fertilization $\mathrm{x}$ arrangement for trunk biomass resulted in significant effect on arrangements $(3.0 \times 3.0 \mathrm{~m}$ and $6.0 \times 1.5 \mathrm{~m})$ at $12,24,36,48$ and 60 months, within treatments $(\mathrm{P} \leq 0.05)$ (Table 4).

T14 in the $6.0 \times 1.5 \mathrm{~m}$ arrangement had the

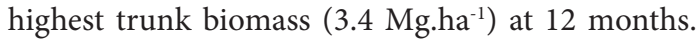
$\mathrm{T} 1(3.0 \times 3.0 \mathrm{~m})$ provided the largest trunk biomass

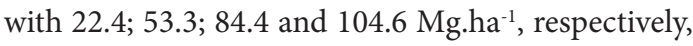
at 24, 36, 48 and 60 months. Treatments with the lowest mean biomass value for these ages were $7,15,13,10$ and 13, respectively, with averages of

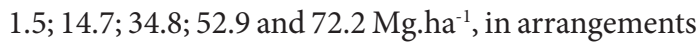
of 6.0 × $1.5 \mathrm{~m} ; 3.0 \times 3.0 \mathrm{~m} ; 6.0 \times 1.5 \mathrm{~m} ; 3.0 \times 3.0 \mathrm{~m}$ and $3.0 \times 3.0 \mathrm{~m}$.

In general, it was observed that arrangement in the square format $(3.0 \times 3.0 \mathrm{~m})$ stood out in relation to the rectangular format $(6.0 \times 1.5 \mathrm{~m})$ when evaluating trunk biomass production over time.

When considering trunk biomass production at 60 months, T1 was approximately 1.45 times higher than T13 (the least productive) for the same arrangement. The second (T14) most productive biomass was approximately $14 \%$ lower than T1 in the same arrangement $(3.0 \times 3.0 \mathrm{~m})$. In treatment with the highest amount of nutrients (T14), biomass production in the $3.0 \times 3.0 \mathrm{~m}$ and $6.0 \times 1.5 \mathrm{~m}$ treatments was 90.3 Mg.ha ${ }^{-1}$ for both, being the second and third in trunk production, respectively. As can be seen, the effect of fertilization becomes less pronounced in relation to trunk production as forest development occurs.

For $\mathrm{N}, \mathrm{Mg}, \mathrm{S}$ and $\mathrm{Zn}$, the corresponding less symbol scale predominates for most treatments (Table 5). It is also observed that most companies use amounts

Table 3. Summary of the analysis of variance for variable trunk biomass $\left(\mathrm{Mg} \cdot \mathrm{ha}^{-1}\right)$ at 12, 24, 36, 48 and 60 months.

\begin{tabular}{|c|c|c|c|c|c|c|}
\hline \multirow{2}{*}{ Source of variation } & \multirow{2}{*}{ DF } & \multicolumn{5}{|c|}{ Middle Square } \\
\hline & & 12 & 24 & 36 & 48 & 60 \\
\hline Blocks & 3 & $0.03^{\text {ns }}$ & $0.52^{\text {ns }}$ & $4.28^{\mathrm{ns}}$ & $13.36^{\mathrm{ns}}$ & $36.05^{\mathrm{ns}}$ \\
\hline Treatment & 14 & $1.14^{*}$ & $24.39^{*}$ & $119.40^{*}$ & $314.03^{*}$ & $501.79^{*}$ \\
\hline Error 1 & 42 & 0.02 & 0.69 & 3.77 & 9.51 & 16.90 \\
\hline Spacing & 1 & $0.26^{\mathrm{ns}}$ & $3.69^{\mathrm{ns}}$ & $22.38^{\mathrm{ns}}$ & $174.82^{*}$ & $9.98^{\text {ns }}$ \\
\hline Error 2 & 3 & 0.11 & 2.52 & 3.73 & 7.65 & 7.94 \\
\hline Treatment $x$ Spacing & 14 & $0.26^{*}$ & $3.84^{*}$ & $14.73^{*}$ & $88.12^{\star}$ & $30.62^{*}$ \\
\hline Error 3 & 42 & 0.03 & 0.82 & 3.95 & 8.48 & 15.22 \\
\hline Total & 119 & & & & & \\
\hline $\mathrm{CV}$ & & 19.03 & 10.71 & 10.63 & 11.68 & 10.58 \\
\hline
\end{tabular}

$\mathrm{DF}=$ degrees of freedom; ${ }^{\mathrm{ns}}=$ not significant; ${ }^{*}=$ significant at $5 \%$ and $\mathrm{CV}=$ experimental variation coefficient $(\%)$. 


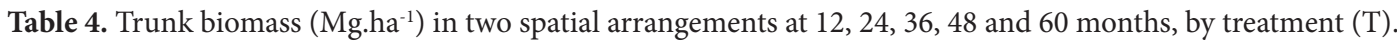

\begin{tabular}{|c|c|c|c|c|c|c|}
\hline \multirow{2}{*}{$\mathbf{T}$} & \multicolumn{2}{|c|}{12 months } & \multicolumn{2}{|c|}{24 months } & \multicolumn{2}{|c|}{36 months } \\
\hline & $3.0 \times 3.0 \mathrm{~m}$ & $6.0 \times 1.5 \mathrm{~m}$ & $3.0 \times 3.0 \mathrm{~m}$ & $6.0 \times 1.5 \mathrm{~m}$ & $3.0 \times 3.0 \mathrm{~m}$ & $6.0 \times 1.5 \mathrm{~m}$ \\
\hline 1 & $2.4 \mathrm{c} \mathrm{A}$ & $2.2 \mathrm{c} \mathrm{A}$ & $22.4 \mathrm{a} A$ & 20.8 a A & 53.3 a A & 45.9 a B \\
\hline 2 & $2.1 \mathrm{~d} \mathrm{~A}$ & $2.5 \mathrm{~b} \mathrm{~A}$ & $21.3 \mathrm{a} A$ & $21.0 \mathrm{a} \mathrm{A}$ & $46.9 \mathrm{~b} \mathrm{~A}$ & 46.0 a $\mathrm{A}$ \\
\hline 3 & $3.0 \mathrm{~b} \mathrm{~A}$ & $2.4 \mathrm{~b} \mathrm{~A}$ & $20.5 \mathrm{~b} \mathrm{~A}$ & $18.3 \mathrm{c} \mathrm{A}$ & $45.2 \mathrm{~b} \mathrm{~A}$ & $41.2 \mathrm{~b} \mathrm{~B}$ \\
\hline 4 & $2.5 \mathrm{c} \mathrm{A}$ & $2.2 \mathrm{c} \mathrm{A}$ & $19.9 \mathrm{~b} \mathrm{~A}$ & $18.8 \mathrm{~b} \mathrm{~A}$ & $45.1 \mathrm{~b} \mathrm{~A}$ & $42.5 \mathrm{~b} \mathrm{~A}$ \\
\hline 5 & 1.7 e A & $1.8 \mathrm{~d} \mathrm{~A}$ & $16.8 \mathrm{c} \mathrm{A}$ & $17.1 \mathrm{~d} \mathrm{~A}$ & 40.7 c A & 39.1 с A \\
\hline 6 & $2.2 \mathrm{~d} \mathrm{~A}$ & $2.4 \mathrm{~b} \mathrm{~A}$ & $18.0 \mathrm{c} \mathrm{A}$ & 19.8 a $\mathrm{A}$ & 40.7 c A & 40.2 c A \\
\hline 7 & 1.8 e A & 1.5 e A & $17.1 \mathrm{c} \mathrm{A}$ & $16.4 \mathrm{~d} \mathrm{~A}$ & $35.9 \mathrm{~d} \mathrm{~A}$ & $37.4 \mathrm{c} \mathrm{A}$ \\
\hline 8 & $1.9 \mathrm{e} \mathrm{A}$ & $2.5 \mathrm{~b} \mathrm{~A}$ & 17.7 c A & 20.3 a A & $37.7 \mathrm{~d} \mathrm{~B}$ & $41.4 \mathrm{~b} \mathrm{~A}$ \\
\hline 9 & $1.9 \mathrm{e} \mathrm{A}$ & $2.6 \mathrm{~b} \mathrm{~A}$ & $19.4 \mathrm{~b} \mathrm{~A}$ & 20.6 a A & $43.0 \mathrm{~b} \mathrm{~A}$ & $43.3 \mathrm{~b} \mathrm{~A}$ \\
\hline 10 & $2.1 \mathrm{e} \mathrm{A}$ & $2.0 \mathrm{c} \mathrm{A}$ & $17.3 \mathrm{c} \mathrm{A}$ & $18.0 \mathrm{c} \mathrm{A}$ & 40.3 c A & $38.5 \mathrm{c} \mathrm{A}$ \\
\hline 11 & $2.0 \mathrm{e} \mathrm{A}$ & $2.4 \mathrm{~b} \mathrm{~A}$ & $17.1 \mathrm{c} \mathrm{A}$ & $18.1 \mathrm{c} \mathrm{A}$ & 40.0 с A & 38.2 c A \\
\hline 12 & $2.3 \mathrm{~d} \mathrm{~A}$ & $2.4 \mathrm{~b} \mathrm{~A}$ & 17.9 c A & $19.1 \mathrm{~b} \mathrm{~A}$ & $37.7 \mathrm{~d} \mathrm{~A}$ & $37.6 \mathrm{c} \mathrm{A}$ \\
\hline 13 & $2.3 \mathrm{~d} \mathrm{~A}$ & $2.2 \mathrm{c} \mathrm{A}$ & $16.1 \mathrm{~d} \mathrm{~A}$ & $16.2 \mathrm{~d} \mathrm{~A}$ & $36.4 \mathrm{~d} \mathrm{~A}$ & $34.8 \mathrm{c} \mathrm{A}$ \\
\hline 14 & 3.3 a A & $3.4 \mathrm{a} \mathrm{A}$ & $20.3 \mathrm{~b} \mathrm{~A}$ & 20.0 a A & 41.4 c A & $42.4 \mathrm{~b} \mathrm{~A}$ \\
\hline 15 & $2.1 \mathrm{~d} \mathrm{~A}$ & $2.5 \mathrm{~b} \mathrm{~A}$ & 14.7 e A & $16.9 \mathrm{~d} \mathrm{~A}$ & $35.4 \mathrm{~d} \mathrm{~A}$ & 38.1 с A \\
\hline \multirow{2}{*}{$\mathbf{T}$} & \multicolumn{3}{|c|}{48 months } & \multicolumn{3}{|c|}{60 months } \\
\hline & $3.0 \times 3.0 \mathrm{~m}$ & & $6.0 \times 1.5 \mathrm{~m}$ & $3.0 \times 3.0 \mathrm{~m}$ & & $6.0 \times 1.5 \mathrm{~m}$ \\
\hline 1 & 84.4 a A & & 69.7 a B & $104.6 \mathrm{a} \mathrm{A}$ & & 97.4 a B \\
\hline 2 & $75.9 \mathrm{~b} \mathrm{~A}$ & & 70.9 a B & 87.2 b B & & 93.6 a A \\
\hline 3 & $73.4 \mathrm{c} \mathrm{A}$ & & $64.2 \mathrm{~b} \mathrm{~B}$ & $85.2 \mathrm{c} \mathrm{A}$ & & 85.6 b A \\
\hline 4 & 71.8 c A & & 64.7 b B & 89.5 b A & & $84.0 \mathrm{c} \mathrm{A}$ \\
\hline 5 & $69.7 \mathrm{~d} \mathrm{~A}$ & & 58.8 c B & $79.9 \mathrm{~d} \mathrm{~A}$ & & $78.1 \mathrm{~d} \mathrm{~A}$ \\
\hline 6 & $67.4 \mathrm{~d} \mathrm{~A}$ & & $63.0 \mathrm{~b} \mathrm{~B}$ & 86.9 c A & & 82.9 c A \\
\hline 7 & $67.2 \mathrm{~d} \mathrm{~A}$ & & 59.7 c B & $76.8 \mathrm{~d} \mathrm{~A}$ & & $78.8 \mathrm{~d} \mathrm{~A}$ \\
\hline 8 & $53.9 \mathrm{fB}$ & & 59.9 c A & $75.9 \mathrm{~d} \mathrm{~A}$ & & $81.2 \mathrm{c} \mathrm{A}$ \\
\hline 9 & 60.7 e $\mathrm{A}$ & & $63.8 \mathrm{~b} \mathrm{~A}$ & $85.2 \mathrm{c} \mathrm{A}$ & & $80.8 \mathrm{c} \mathrm{A}$ \\
\hline 10 & $52.9 \mathrm{fB}$ & & $58.1 \mathrm{c} \mathrm{A}$ & $73.6 \mathrm{~d} \mathrm{~A}$ & & $74.2 \mathrm{~d} \mathrm{~A}$ \\
\hline 11 & $62.4 \mathrm{e} \mathrm{A}$ & & 59.9 c A & 80.3 c A & & $76.0 \mathrm{~d} \mathrm{~A}$ \\
\hline 12 & $54.7 \mathrm{f} \mathrm{A}$ & & 57.9 c A & $73.5 \mathrm{~d} \mathrm{~A}$ & & $74.9 \mathrm{~d} \mathrm{~A}$ \\
\hline 13 & 58.3 e $\mathrm{A}$ & & 59.3 c A & $72.2 \mathrm{~d} \mathrm{~A}$ & & $73.5 \mathrm{~d} \mathrm{~A}$ \\
\hline 14 & $66.8 \mathrm{~d} \mathrm{~A}$ & & $66.8 \mathrm{~b} \mathrm{~A}$ & 90.3 a $\mathrm{A}$ & & $90.3 \mathrm{~b} \mathrm{~A}$ \\
\hline 15 & $56.3 \mathrm{f} \mathrm{B}$ & & $62.9 \mathrm{~b} \mathrm{~A}$ & $72.6 \mathrm{~d} \mathrm{~A}$ & & $74.4 \mathrm{~d} \mathrm{~A}$ \\
\hline
\end{tabular}

Same lowercase letters in each column indicate equality between means estimated for each treatment, within each age assessed, by the Scott Knott test $(\mathrm{P}>0.05)$. Same capital letters in each row indicate equality between the means estimated for each arrangement within each age evaluated by the Scott Knott test $(\mathrm{P}>0.05)$.

Table 5. Total amount of nutrients applied per treatment $(\mathrm{T})$ empirically grouped by similar symbols in the column, depending on the amount of fertilizer applied.

\begin{tabular}{|c|c|c|c|c|c|c|c|c|c|}
\hline \multirow{2}{*}{$\mathbf{T}$} & $\mathbf{N}$ & $\mathbf{P}$ & $\mathbf{K}$ & $\mathrm{Ca}$ & Mg & $S$ & B & $\mathrm{Cu}$ & $\mathrm{Zn}$ \\
\hline & \multicolumn{9}{|c|}{ kg.hat } \\
\hline $\mathrm{T} 1$ & $5.2^{\circ}$ & $34.1^{+}$ & $87.7^{+}$ & $703.3^{*}$ & $144.7^{*}$ & $6.7^{\circ}$ & $1.5^{\circ}$ & $0.7^{+}$ & $0.7^{\circ}$ \\
\hline $\mathrm{T} 2$ & $69.0^{\#}$ & $44.0^{\#}$ & $57.3^{\circ}$ & $643.2^{*}$ & $126.7^{\#}$ & $223.1^{*}$ & $4.3^{\#}$ & $1.5^{\#}$ & $2.3^{+}$ \\
\hline T3 & $20.9^{+}$ & $34.7^{+}$ & $126.7^{+}$ & $463.1^{+}$ & $126.7^{\#}$ & $3.2^{\circ}$ & $0.9^{\circ}$ & $0.0^{-}$ & $0.0^{-}$ \\
\hline $\mathrm{T} 4$ & $6.6^{\circ}$ & $32.9^{+}$ & $116.9^{+}$ & $553.2^{\#}$ & $108.6^{+}$ & $6.1^{\circ}$ & $6.9^{*}$ & $2.1^{*}$ & $3.6^{\#}$ \\
\hline T5 & $6.0^{\circ}$ & $30.8^{\circ}$ & $139.5^{\#}$ & $473.1^{+}$ & $54.3^{\circ}$ & $4.8^{\circ}$ & $3.5^{+}$ & $0.0^{-}$ & $0.5^{\circ}$ \\
\hline T6 & $9.0^{\circ}$ & $23.6^{\circ}$ & $144.4^{\#}$ & $405.3^{\circ}$ & $54.3^{\circ}$ & $3.0^{\circ}$ & $3.9^{\#}$ & $0.6^{+}$ & $0.6^{\circ}$ \\
\hline T7 & $6.0^{\circ}$ & $35.8^{+}$ & $139.5^{\#}$ & $524.6^{\#}$ & $54.3^{\circ}$ & $0.0^{-}$ & $3.5^{+}$ & $0.0^{-}$ & $0.5^{\circ}$ \\
\hline $\mathrm{T} 8$ & $9.0^{\circ}$ & $64.2^{\star}$ & $137.0^{\#}$ & $386.6^{\circ}$ & $55.6^{\circ}$ & $19.8^{+}$ & $3.9^{\#}$ & $0.8^{+}$ & $0.8^{\circ}$ \\
\hline T9 & $9.0^{\circ}$ & $64.2^{*}$ & $145.1^{\#}$ & $458.0^{+}$ & $44.4^{\circ}$ & $19.8^{+}$ & $4.1^{\#}$ & $0.8^{+}$ & $0.8^{\circ}$ \\
\hline T10 & $6.0^{\circ}$ & $34.0^{+}$ & $169.8^{*}$ & $393.1^{\circ}$ & $126.4^{\#}$ & $240^{*}$ & $4.7^{\#}$ & $0.8^{+}$ & $18.5^{\star}$ \\
\hline T11 & $41.1^{\#}$ & $81.7^{\star}$ & $153.9^{*}$ & $514.6^{\#}$ & $168.9^{\star}$ & $0.0^{-}$ & $3.2^{+}$ & $0.8^{+}$ & $0.8^{\circ}$ \\
\hline T12 & $8.4^{\circ}$ & $34.0^{+}$ & $156.4^{*}$ & $231.6^{\circ}$ & $42.2^{\circ}$ & $4.2^{\circ}$ & $3.4^{+}$ & $1.4^{\#}$ & $1.4^{+}$ \\
\hline T13 & $22.0^{+}$ & $39.7^{\#}$ & $23.2^{\circ}$ & $551.8^{\#}$ & $81.4^{+}$ & $0.0^{-}$ & $3.1^{+}$ & $0.0^{-}$ & $0.0^{-}$ \\
\hline T14 & $156.0^{*}$ & $43.2^{\#}$ & $179.3^{\star}$ & $626.8^{*}$ & $168.9^{\star}$ & $65.0^{\#}$ & $0.8^{\circ}$ & $0.0^{-}$ & $0.8^{\circ}$ \\
\hline T15 & $45.0^{\#}$ & $42.3^{\#}$ & $32.4^{\circ}$ & $542.9^{\#}$ & $126.7^{\#}$ & $6.4^{\circ}$ & $7.5^{\star}$ & $0.0^{-}$ & $0.0^{-}$ \\
\hline
\end{tabular}

${ }^{*}=$ Very high; ${ }^{*}=$ High $^{+}=$Intermediate ${ }^{\circ}=$ Low; ${ }^{-}=$Not applied. 
between the high and intermediate scale for $\mathrm{P}, \mathrm{K}$ and $\mathrm{Ca}$, and three or more companies adopting very high values. Moreover, most companies adopt amounts between high and intermediate scale for $\mathrm{B}$ and $\mathrm{Cu}$, although $\mathrm{Cu}$ is not applied in some recommendations (T3, T5, T7, T13, T14 and T15). T1 presented very high amounts of $\mathrm{Ca}$ and $\mathrm{Mg}$, however without presenting higher trunk biomass production over time.

\section{DISCUSSION}

The main feature of Benchmark is the relative performance evaluation among treatments of interest. This work evaluated the effects of commercial fertilizations used by large companies operating in the state of Minas Gerais on eucalyptus production. The analysis was based on the joint effect of fertilization on production. This comparison is important because there is not a single fertilization recommendation for eucalyptus adopted by producing companies.

Since all companies generally adopt the nutritional balance method to define fertilization, there should be no major discrepancies in recommendations. In literature, it is common to observe different fertilization recommendations in similar areas, although there are no compatible economic gains with the highest amounts of applied nutrients. This study showed large discrepancies in productive terms (Table 4), and the results observed by Stape et al. $(2008,2010)$ and Oliveira et al. (2010) corroborate such affirmation.

From the second year, T1 stood out as the most productive (Table 4). This received only $3.3 \%$ of the amount of $\mathrm{N}$ and $48.9 \%$ with respect to $\mathrm{K}$, which were applied in T14 (Table 5). For the region under study, it is evident that there is no need to apply high amounts of $\mathrm{N}$, a fact that is observed in different Brazilian regions (Stape et al., 2008, 2010; Oliveira et al., 2010). In addition to not promoting greater productivity gains, this nutrient significantly impacts the fertilization cost and is environmentally undesirable, as it produces nitrous oxide $\left(\mathrm{N}_{2} \mathrm{O}\right)$ and contribute to the emission of greenhouse gases (Bichel et al., 2016).

$\mathrm{T} 1$ produced about 1.45 times more aerial biomass than T13 (the least productive) (Table 4), evidencing the high productive capacity of this fertilization for the region. The mean biomass of $\mathrm{T} 1$ (Table 4) at 60 months was similar to that found by Meneses et al. (2015) (107.4 Mg.ha ${ }^{-1}$ ) at the same site, and higher than the average production found by Stape et al. (2010) (100.0 Mg.ha $\left.{ }^{-1}\right)$ in the northern region of Minas Gerais at that same age, indicating the potential of this fertilization for the region. The higher growth in trunk biomass in response to $\mathrm{T} 1$ confirms the importance of fertilization to reach high productivity of forests planted in Savana soils. The direct and positive relationship between productivity and forest nutrition is widely demonstrated in literature (Santana et al., 1999; Stape et al., 2010; Pulito et al., 2015), until water becomes a factor limiting productivity.

T14 presented higher trunk biomass at 12 months in both arrangements in relation to the other treatments. However, the growth rate decreased from the second year. A possibility of this occurrence may have been the fact that this treatment received large amounts of nutrients, mainly $\mathrm{N}$ and $\mathrm{K}$ (Table 5). In addition to the fact that these two nutrients are among the most expensive, they are mainly responsible for the initial growth of plants (Santana et al., 2002; Pulito et al., 2015). In a study conducted in the state of São Paulo, eucalyptus positively responded to increased fertilizer doses, resulting in increased productivity; however, the effects of higher doses decreased from the second year of planting (Silva et al., 2013). Similar results were also observed by Pulito et al. (2015) and Stape et al. (2010). In studying the fertilization response in eucalyptus production in savanna soils, Barros et al. (1981) found that fertilization is essential to obtain good yields, and that the growth rate in the first two years is differentiated according to fertilization, but tends to equalize over time.

It is emphasized that the amount of each nutrient should be applied according to the plant assimilability to maintain nutrient concentrations in plant tissues at appropriate levels. In addition to the amount of nutrients applied, the proportion of nutrients should also be considered. The results show that the growth rate of eucalyptus in treatments with the highest amount of nutrients reduced from the second year. This occurred after the canopy phase, which means that plants occupied the total area and intraspecific competition for water and light became more growth restrictive. The results observed by Stape et al. $(2008,2010)$ and Silva et al. (2013) corroborate those observed in this study. Barros et al. (2005) pointed out that the higher proportion of nutrients required by fast-growing forest species such as eucalyptus should be provided up to a maximum of three years. After this age, biochemical 
and biogeochemical cycling processes are able to meet the nutrient demand until the end of the rotation.

Regarding arrangements, the square arrangement in most treatments produced higher trunk biomass compared to the rectangular arrangement. This occurred from 36 months, because there was no difference between arrangements for all treatments until this age (Table 4), which means that competition for resources was lower or even non-existent until this age. From 36 months, competition for resources in the rectangular arrangement was higher, a fact that was probably related to the competition of trees in the planting line, where it restricted and increased competition for light, nutrients and water. However, a factor that must be taken into consideration in relation to arrangements is tree harvesting. In rectangular spacing, the harvesting cost is lower in relation to square arrangements (Martins et al., 2009; Leite et al., 2014), significantly increasing the final production cost of square arrangements.

\section{CONCLUSION}

Benchmark has been shown to be an adequate strategy to resolve uncertainties about the effect of different fertilizations and spatial arrangements on eucalyptus wood production.

Biological response expressed in higher biomass production, occurred in association with higher amounts of fertilizer applied in the first years of cultivation. This effect reduced after two years and became less expressive at the end of the cutting cycle.

Fertilization of $2000 \mathrm{~kg}$ of agrosilicon, $400 \mathrm{~kg}$ of reactive phosphate, $130 \mathrm{~kg}$ of $04: 26: 16+0.5 \% \mathrm{Cu}+0.5 \% \mathrm{Zn}$ and $150 \mathrm{~kg}$ of $\mathrm{KCl}+1 \% \mathrm{~B}$ per hectare in the $3.0 \times 3.0 \mathrm{~m}$ arrangement proved to be the most attractive option according to trunk production at 60 months.

\section{ACKNOWLEDGEMENTS}

To the Federal University of "Vales do Jequitinhonha and Mucuri" - UFVJM, Fundação de Amparo à Pesquisa de Minas Gerais - FAPEMIG, Conselho Nacional de Pesquisa e Desenvolvimento - CNPq, Coordenação de Aperfeiçoamento de Pessoal de Nível Superior - CAPES - Finance Code 001 and Gerdau Forestry Company for the financial support directly or indirectly provided to this work.

\section{SUBMISSION STATUS}

Received: 15 may 2017

Accepted: 27 mar., 2018

\section{CORRESPONDENCE TO}

\section{Paulo Henrique Rodrigues dos Santos}

Departamento de Engenharia Florestal, Universidade Federal dos Vales do Jequitinhonha e Mucuri - UFVJM, Rodovia MGT 367, Km 583, 5000, Alto da Jacuba, CEP 39100-000, Diamantina, MG, Brasil e-mail: santosphr@gmail.com

\section{REFERENCES}

Barros NF, Braga JM, Brandi RM, Defelipo BV. Produção de eucalipto em solos de cerrados em resposta à aplicação de NPK e de B e Zn. Revista Árvore 1981; 5: 90-103.

Barros NF, Neves JCL, Novais RF. Fertilidade de solos, nutrientes e produção florestal. Visão Agrícola 2005; 14: 76-79.

Bichel A, Oelbermann M, Echarte L. Impact of residue addition on soil nitrogen dynamics in intercrop and sole crop agroecosystems. Geoderma 2016

Ferreira DF. Sisvar: a computer statistical analysis system. Ciência e Agrotecnologia 2011; 35(6): 1039-1042. http:// dx.doi.org/10.1590/S1413-70542011000600001.

Gonçalves JLM, Stape JL, Laclau JP, Bouillet JP, Ranger J. Assessing the effect so fearly silvicultural management on long-term site productivity off ast-growing eucalypt plantations: the Brazilian experience. Southern Forests 2008; 70(2): 105-118.

Leite ES, Minette LJ, Fernades HC, Souza AP, Amaral EJ, Lacerda EG. Desempenho do harvester na colheita de eucalipto em diferentes espaçamentos e declividades. Revista Árvore 2014; 38(1): 1-8. http://dx.doi.org/10.1590/ S0100-67622014000100009.

Macedo-Soares TDLVA, Ratton CA. Medição de desempenho e estratégias orientadas para o cliente: resultados de uma pesquisa de empresas líderes no Brasil. Revista de Administração de Empresas 1999; 39(4): 46-59. http:// dx.doi.org/10.1590/S0034-75901999000400006.

Magalhães WM, Macedo RLG, Venturim N, Higashikawa EM, Manabu MY Jr. Desempenho silvicultural de espécies de Eucalyptus spp. em quatro espaçamentos de plantio na região noroeste de Minas Gerais. Floresta e Ambiente 2006; 12(2): 1-7.

Martins RJ, Seixas F, Stape JL. Avaliação técnica e econômica de um harvester trabalhando em diferentes condições 
de espaçamento e arranjo de plantio em povoamento de eucalipto. Scientia Forestalis 2009; 37(83): 253-263.

Meneses VA, Trugilho PF, Calegario N, Leite HG. Efeito da idade e do sítio na densidade básica e produção de massa seca de madeira em um clone do Eucalyptus urophylla. Scientia Forestalis 2015; 43(105): 101-116.

Oliveira SN No, Reis GG, Reis MGF, Leite HG, Neves JCL. Crescimento e distribuição diamétrica de Eucalyptus camaldulensis em diferentes espaçamentos e níveis de adubação na região de cerrado de Minas Gerais. Floresta 2010; 40(4): 755-762. http://dx.doi.org/10.5380/ rf.v40i4.20327.

Pulito AN, Gonçalves JLM, Smethurst PJ, Arthur CA Jr, Alvares CA, Rocha JHT et al. Available nitrogen and responses to nitrogen fertilizer in brazilian eucalypt plantations on soils of contrasting texture. Forests 2015; 6(12): 973-991. http://dx.doi.org/10.3390/f6040973.

Santana RC, Barros NF, Neves JCL. Biomassa e conteúdo de nutrientes de procedências de Eucalyptus grandis e Eucalyptus saligna em alguns sítios florestais do Estado de São Paulo. Scientia Forestalis 1999; 56: 155-169.

Santana RC, Barros NF, Neves JCL. Eficiência de utilização de nutrientes e sustentabilidade da produção em procedências de Eucalyptusgrandis e Eucalyptussaligna em sítios florestais do estado de São Paulo. Revista Árvore 2002; 26(4): 447-457. http://dx.doi.org/10.1590/S010067622002000400007 .

Santana RC, Barros NF, Novais RF, Leite HG, Comerford NB. Alocação de nutrientes em plantios de eucalipto no Brasil. Revista Brasileira de Ciência do Solo 2008; 32(spe): 2723-2733. http://dx.doi.org/10.1590/S010006832008000700016 .

Silva PHM, Poggiani F, Libardi PL, Gonçalves AN. Fertilizer management of eucalypt plantations on sandy soil in Brazil: Initial growth and nutrient cycling. Forest Ecology and Management 2013; 301: 67-78. http://dx.doi. org/10.1016/j.foreco.2012.10.033.

Smethurst P, Baillie C, Cherry M, Holz G. Fertilizer effects on LAI and growth of four Eucalyptus nitensplantations. Forest Ecology and Management 2003; 176(1-3): 531-542. http://dx.doi.org/10.1016/S0378-1127(02)00226-8.

Stape JL, Binkley D, Ryan MG, Fonseca S, Loos RA, Takahashi EN et al. The Brazil eucalyptus potential productivity project: influence of water, nutrients and stand uniformity on wood production. Forest Ecology and Management 2010; 259(9): 1684-1694. http://dx.doi. org/10.1016/j.foreco.2010.01.012.

Stape JL, Binkley D, Ryan MG. Production and carbon allocation in a clonal Eucalyptus plantation with water and nutrient manipulations. Forest Ecology and Management 2008; 255(3): 920-930. http://dx.doi.org/10.1016/j. foreco.2007.09.085.

Tarouco CP, Agostinetto D, Panozzo LE, Santos LS, Vignolo GK, Ramos LOO. Períodos de interferência de plantas daninhas na fase inicial de crescimento do eucalipto. Revista Pesquisa Agropecuária Brasileira 2009; 44(9): 1131-1137.

Whitehead D, Beadle CL. Physiological regulation of productivity and water use in Eucalyptus: a review. Forest Ecology and Management 2004; 193(1-2): 113-140. http:// dx.doi.org/10.1016/j.foreco.2004.01.026. 